University of Nebraska - Lincoln

DigitalCommons@University of Nebraska - Lincoln

Papers in Ornithology

Papers in the Biological Sciences

1969

\title{
The Masked Duck in the United States
}

Paul A. Johnsgard

University of Nebraska-Lincoln, pajohnsgard@gmail.com

Dirk Hagemeyer

Sheffield, Texas

Follow this and additional works at: https://digitalcommons.unl.edu/biosciornithology

Part of the Ornithology Commons

Johnsgard, Paul A. and Hagemeyer, Dirk, "The Masked Duck in the United States" (1969). Papers in Ornithology. 60.

https://digitalcommons.unl.edu/biosciornithology/60

This Article is brought to you for free and open access by the Papers in the Biological Sciences at DigitalCommons@University of Nebraska - Lincoln. It has been accepted for inclusion in Papers in Ornithology by an authorized administrator of DigitalCommons@University of Nebraska - Lincoln. 


\section{THE MASKED DUCK IN THE UNITED STATES}

\section{Paul A. Johnsgard and Dirk Hagemeyer}

UNTIL fairly recently, the neotropical Masked Duck (Oxyura dominica) had been reported within the continental United States only a few times. Between 1857 and 1905 single accidental records of the species were made in Vermont, Massachusetts, Wisconsin, and Maryland (Bent, 1925). Only the Rio Grande area of Cameron County, Texas, where Fisher (1895) first reported the sighting of several Masked Ducks and the collection of a female specimen near Brownsville in July 1891, has been considered a potential breeding locality. Griscom and Crosby (1925) mention a male specimen, taken in the same place at the same time, and Lawrence (1927) reports a specimen killed in Brazoria County, Texas. A female Masked Duck was shot in Louisiana during December of 1933 (Lowery, 1955), one was reported near Harlingen (Cameron County), Texas in December of 1936 (Bird-Lore, 39: 65, 1937), and a flock of 24 was reported at Aransas National Wildlife Refuge (Aransas County), Texas in December of 1948 (Audubon Field Notes, 3: 177, 1949). As Masked Ducks are not known ever to have been kept in captivity in the United States (Delacour, 1959), it is unlikely that these early records represent escaped birds.

In September 1937 Loetscher (1956) observed a group of eight Masked Ducks near Brownsville, including two males in nuptial plumage. Loetscher presumed that the five female-like birds may have included young of both sexes. Prior to 1941 L. I. Davis repeatedly observed single Masked Ducks near Harlingen, and, although no nest was located, he believed (1966) that they attempted to breed there in 1941, when five possible immatures were seen. These two cases apparently represent the only reported instances of possible breeding by Masked Ducks in the United States prior to 1967 .

During the 1950s three Masked Ducks were reported from Florida, including a bird found dead at Key West in 1955 (Hames, 1956), one shot during the 1956-57 hunting season in Glades County, and one shot during 1957 in Palm Beach County (Owre, 1962). Texas reports include a female seen near Santa Ana National Wildlife Refuge (Hidalgo County) during March of 1957 (A.F.N., 11: 362, 1957) and a female observed on Laguna Atascosa National Wildlife Refuge (Cameron County) in October of 1959 (A.F.N., 14: 53, 1960).

The early 1960s brought about a surprising number of new Masked Duck reports, often shortly after the passage of Caribbean hurricanes. These included the sighting of a male on Brigantine National Wildlife Refuge, New Jersey, in December 1960 (A.F.N., 15: 315, 1961), a bird 
seen and photographed near Valdosta, Georgia in April of 1962 (A.F.N., 17: 23, 1963), and records at the Loxahatchee National Wildlife Refuge, Florida in both 1962 (three birds seen) and 1963 (one collected) (A.F.N., 16: 323, 1962; 17: 321, 1963). A male was also reported for the second time in 4 years near Lantana, Florida during December of 1966 (A.F.N., 21: 409, 1967). Finally, a male was reported seen in western Iowa in March 1965 (Iowa Bird Life, 35: 50, 1965).

Texas reports of Masked Ducks obtained during the 1960s include a female seen in Kenedy County, November 1962 (A.F.N., 16: 56, 1962), four observed in the vicinity of Alice (Jim Wells County) during March 1964 (A.F.N., 18: 468, 1964), a female on Santa Ana National Wildlife Refuge during late September and early October of 1966 (A.F.N., 21: 55, 1967), a male at La Sal Vieja, Willacy County in December of 1967 (A.F.N., 22: 334, 1968), and a pair that was present for a prolonged period on a large natural pond within the city limits of Corpus Christi during 1967 (Clarence Cottam, in litt.). A male was seen in August of 1968 near Port O'Connor, Calhoun County, by Hazel C. Green, and a Masked Duck was reportedly shot in the spring of 1967 in the lower Rio Grande valley (Noel Pettingill, in litt.). Laguna Atascosa records of Masked Ducks in the 1960s include a male seen on 1 September 1963 (Henry Hoffman, pers. comm.), several sightings of adults during the winter and spring of 1967-68 (F. S. Webster, in litt.), a male found dead on January 31, 1968, and a pair observed on 10 and 11 July 1968 (Richard Smith, pers. comm.). Finally during October of 1968 two males in full plumage and a female were repeatedly observed on Brazoria National Wildlife Refuge (Brazoria County) by manager R. J. Fleetwood (pers. comm.).

The autumn of 1967 marked the first definite record of breeding by Masked Ducks within the United States. On 2 October a brood of four small ducklings and two adults in female plumage were found by $R$. W. Clapper in Anahuac National Wildlife Refuge, Chambers County, Texas (A.F.N., 22: 65, 1968; The Spoonbill, 18: nos. 6-8). This brood was later seen repeatedly and photographed by Dirk Hagemeyer. A third female-like adult was located on 9 October and a fifth immature bird, seemingly several weeks younger than the others, was discovered 16 November. The other young disappeared at about this time, and the single immature bird was last seen 22 November. Masked Ducks were not seen again on the refuge until 29 June 1968, when Hagemeyer located a single male. A second definite breeding record, involving a nest with six eggs that hatched successfully, was obtained in the autumn of 1968 near Falfurrias, Brooks County, Texas (A.F.N., 22: 625, 1968).

Hagemeyer's observations correspond to those made by Johnsgard in 
Colombia, in that Masked Ducks typically fly very low, have a rapid wingbeat, and appear to be unusually swift in flight. As also indicated by Slud (1964), Wetmore (1965), and Weller (1968), they sometimes take flight in a manner similar to that of dabbling ducks. Furthermore they are quite agile on solid ground; Hagemeyer saw adults readily climb up on marsh grasses to scan the surrounding area. Neither of us has heard any adult vocalizations, but Hagemeyer heard the immatures utter highpitched whistled peeping sounds.

Male courtship displays and calls of Masked Ducks are still only poorly understood. One account (Ginés and Aveledo, 1958) indicates that the male cocks its tail, inflates its breast, thrusts its neck back and forth, and strikes the breast with its bill. It also reportedly utters "kuak-kuak" sounds and vigorously splashes with both feet. Similar observations to these have been made by L. I. Davis (Johnsgard, 1967). Other reported male calls include a repeated "kirri-kirro," a cock pheasant-like response to various loud noises (Barbour, 1923), and a dull, almost inaudible "oo-oooo" (Slud, 1964). The female is said to make repeated hissing sounds, and vocalizations not specifically identified as to sex include hen-like clucking calls and one sounding like a motor horn (English, 1916).

Although Delacour (1959) indicates that three or four eggs comprise a clutch, Wetmore (1965) states that four to six are in an average clutch, which agrees with most brood observations. Bond (1961) mentions eight Cuban clutches containing from 8 to 18 eggs, which strongly suggests that nest parasitism may be prevalent at times.

Almost nothing is definitely known about the plumage sequences or the breeding periods of this tropical species. On the basis of 116 specimens examined in the British Museum (Natural History), the Field Museum of Natural History, and the American Museum of Natural History, a few observations regarding plumages can be made. Of 41 skins clearly identified as males, only 16 are in definitive nuptial plumage. Seven more closely approach this condition but have mottled brown striping on the black facial "mask." Eight have distinctly striped and female-like head patterns, but show a largely ruddy body coloration, and five more are not readily separable from females. This large number of female-like birds indicates either that a prolonged sub-adult condition might exist (see Phillips, 1926), or that a definite and prolonged "eclipse" plumage may be present. This latter would appear to be more probable as, contrary to Delacour (1959), males of all other Oxyura species are now known to have femalelike nonbreeding plumages. An eclipse plumage should be most evident in males molting their remiges, but such specimens appear to be rare in collections. One puzzling "immature male" specimen (\#13273, Conover collection) from Paraguay in the Field Museum has a female-like head 
pattern and is molting its rectrices, which are of adult type. The distal four or five primaries seem to be lacking, but actually are present and of greatly reduced size. After this manuscript was completed, Mrs. J. B. Payne (in litt.) reported a small flock of Masked Ducks near Corpus Christi, Texas, which included a male that gradually lost his nuptial plumage and became more female-like during November and early December 1968.

The times of breeding in Masked Ducks seem to be highly variable. Eggs have been collected in Cuba from early June until September (Bond, 1960). June breeding has been suspected, but not proved, for western Mexico (Leopold, 1959), and a female collected in Yucatan in November had a fully formed egg in her oviduct (Bent, 1925). Eggs and ducklings have been collected in Martinique during December ( $\mathrm{J}$. Bond, in litt.). In Panama a brood was seen in early December (Wetmore, 1965), and a female taken there in March had enlarged ovaries (specimen in A.M.N.H.). Well-grown juveniles still carrying juvenal rectrices have been collected during December (Mexico), January (Costa Rica, Cuba), February (Costa Rica, Colombia) and March (Venezuela) in the northern hemisphere, during February and September in Ecuador, and during November in northern Peru. Probable November breeding has been indicated for Argentina (Holland, 1892). Male specimens in apparent breeding plumage have been taken in January (Panama), February (Ecuador, Brazil), July (Texas, Costa Rica), August (Massachusetts, Costa Rica), September (Mexico, northern Peru), October (Trinidad), and December (Costa Rica and Panama). The Field Museum has six full plumaged males from Paraguay that were taken between 12 January and 26 March, except for one collected in September. Two other February specimens, although labelled as immature males, lack juvenal rectrices and are more female-like. One of these is the specimen mentioned earlier as exhibiting a confusing wing molt.

These specimen and nesting records all suggest a quite prolonged or irregular breeding periodicity in the tropical regions of South and Central America, and mid-summer or autumn nesting in the northern West Indies and presumably Mexico. Probably the range map for Masked Ducks shown in Delacour (1959) should be extended north to include at least some parts of Mexico (Arellano and Rojas, 1956; Leopold, 1959). The recent Texas occurrences have most likely had a Mexican origin, but reports from Florida and the East Coast more probably represent stormcarried birds from Cuba. The next few years should clarify whether the present influx of Masked Ducks into Texas is a temporary phenomenon, or whether the species is actually extending its range appreciably northward. 


\section{Literature Cited}

Arellano, M., And P. Rojas. 1956. Aves Acuáticas Migratorias en México, 1. México, D. F., Instituto Mexicano de Recursos Naturales Renovables, A. C.

Barbour, T. 1923. The birds of Cuba. Mem. Nuttall Ornithol. Club, 6: 1-141.

Bent, A. C. 1925. Life histories of North American wild fowl. U. S. Natl. Mus., Bull. 130: 1-316.

Bond, J. 1960. Fifth supplement to the check-list of birds of the West Indies (1956). Philadelphia, Acad. Nat. Sci.

Bond, J. 1961. Sixth supplement to the check-list of birds of the West Indies (1956). Philadelphia, Acad. Nat. Sci.

Davis, L. I. 1966. Birds of the Rio Grande Delta Region, an annotated check-list. Privately published (mimeo).

Delacour, J. 1959. The waterfowl of the world, vol. 3. London, Country Life Ltd.

ENGLish, T. M. S. 1916. Notes on some of the birds of Grand Cayman, West Indies. Ibis, 4, 10th Ser.: 17-35.

FIsher, A. K. 1895. The Masked Duck (Oxyura dominicus) in the lower Rio Grande Valley, Texas. Auk, 12: 297.

Ginés, H., And H. Aveledo. 1958. Aves de caza de Venezuela. Monogr. 4, Soc. Cien. nat. La Salle.

Griscom, L., ANd M. S. Crosby. 1925. Birds of the Brownsville region, southern Texas. Auk, 42: 432-440, 519-537.

Hames, F. 1956. Masked Duck in Florida. Auk, 73: 291.

Holland, A. H. 1892. Short notes on the birds of Estancia Espartilla, Argentine Republic. Ibis, 4, 6th Ser.: 193-214.

Johnsgard, P. A. 1967. Observations on the behavior and relationships of the White-backed Duck and the stiff-tailed ducks. Wildfowl Trust, 18th Ann. Rept.: 98-107.

Lawrence, R. B. 1927. Masked Duck (Nomonyx dominicus) in Texas. Auk, 44: 415.

Leopold, A. S. 1959. Wildlife of Mexico. Berkeley. Univ. California Press.

Loetscher, F. W. 1956. Masked Duck and Jacana at Brownsville, Texas. Auk, 73: 291.

Lowery, G. H., JR. 1955. Louisiana Birds. Baton Rouge, Louisiana State Univ. Press.

OWRE, O. T. 1962. The first record of the King Eider, Somateria spectabilis, and the occurrence of other Anseriformes in Florida. Auk, 79: 270-271.

PHitlips, J. C. 1926. A natural history of the ducks, vol. 4. Boston, Houghton Mifflin Co.

SLud, P. 1964. The birds of Costa Rica. Bull. Amer. Mus. Nat. Hist., 118: 1-430.

Weller, M. W. 1968. Notes on some Argentine anatids. Wilson Bull., 80: 189212.

WetMore, A. 1965. The birds of the Republic of Panama, part 1. Smithsonian Misc. Coll., 150: 1-483.

Department of Zoology, University of Nebraska, Lincoln, Nebraska 68508 and 1117 Sheffield, Bellaire, Texas 77401. 